\title{
1 High goose abundance reduces nest predation risk in a simple
}

\section{2 rodent-free high-Arctic ecosystem}

3 Åshild $\varnothing$. Pedersen ${ }^{1}$, Jennifer Stien ${ }^{4}$, Pernille B. Eidesen ${ }^{2}$, Rolf A. Ims ${ }^{3}$, Jane U. Jepsen ${ }^{4}$, Audun

4 Stien ${ }^{4}$, Ingunn Tombre ${ }^{4}$, Eva Fuglei ${ }^{1}$

$5{ }^{1}$ Norwegian Polar Institute (NPI), Fram Centre, NO-9296 Troms $\varnothing$, Norway

62 The University Centre in Svalbard (UNIS), Postbox 156, NO-9171 Longyearbyen, Norway

$7{ }^{3}$ UiT Arctic University of Norway, Department of Arctic and Marine Biology, Postboks 6050

8 Langnes, NO-9037 Troms $\varnothing$, Norway

$9{ }^{4}$ Norwegian Institute for Nature Research (NINA), Arctic Ecology Department, Fram Centre,

10 NO-9296 Tromsø, Norway

11 Corresponding author: Åshild $\varnothing$. Pedersen, NPI, Fram Centre, NO-9296 Troms $\varnothing$, Norway, +47

12777505 00, e-mail: aashild.pedersen@npolar.no 


\section{Abstract}

Breeding geese are the preferred prey of the Arctic fox Vulpes lagopus in the high-Arctic Svalbard archipelago. According to the apparent competition hypothesis $(A C H)$, less abundant prey species (e.g. ptarmigan, waders and small passerines) will experience higher predation rates when breeding in association with the more common prey (geese), due to spill-over predation by the shared predator. As many of these less abundant species are endemic and/ or red-listed, increased predation can have negative repercussions on their populations. We used a one-year baited artificial nest study to assess relative nest predation risk on Svalbard Rock Ptarmigan Lagopus muta hyperborea, small waders (Purple Sandpiper Calidris maritima, Dunlin Calidris alpina, plovers Charadrius spp., and phalaropes Phalaropus spp.) and Snow bunting Plectrophenax nivalis in two study locations contrasted by nesting density of Arctic breeding geese (Pink-footed Goose Anser brachyrhynchus and Barnacle Goose Branta leucopsis). We predicted higher predation risk for the less abundant species in the study location with higher goose abundance. However, we found that relative nest predation risk was lower in the study location with higher goose abundance, thus being compatible with apparent mutualism and / or prey swamping mechanisms. Our results contrast with those from more structurally complex Arctic ecosystems and suggest that allochtonous subsidies from temperate ecosystems structure the predation pattern in this high-Arctic tundra ecosystem.

Key words: Apparent competition, Arctic fox V. lagopus, artificial nest, predator, Pink-footed Goose, Svalbard 


\section{Introduction}

Recent circumpolar studies have demonstrated that at high latitudes, predation can exert strong top-down control on small to medium-sized vertebrates and be a major driver of their population dynamics (Legagneux et al. 2012; Legagneux et al. 2014). In tundra ecosystems lacking lemmings and voles, key resources for predators are typically geese, seabirds and carrion from reindeer Rangifer tarandus platyrhynchus and seals (Jepsen et al. 2002; Fuglei et al. 2003; Eide et al. 2005; Eide et al. 2012; Giroux et al. 2012; McKinnon et al. 2013, 2014). The magnitude of such resources may be decisive in structuring predation patterns (Tombre et al. 1998; Jepsen et al. 2002; Fuglei et al. 2003; Roth 2003; Eide et al. 2012) including the level of predation on less preferred prey such as smaller ground-nesting birds (Bety et al. 2001; McKinnon et al. 2013, 2014).

Abundant prey availability may attract predators and can lead to increased predator densities in proximity to prey (Giroux et al. 2012). According to the apparent competition hypothesis (Holt and Kotler 1987), an increase in the abundance of a predator's main prey (in time or space) can cause spill-over predation on alternative prey (lles et al. 2013; McKinnon et al. 2013). However, the relationship is complex as high availability of main prey can also buffer predation on alternative prey, resulting in a positive relationship between the two (i.e. apparent mutualism (Abrams and Matsuda 1996; Abrams et al. 1998)). The occurrence of contrasting abundances of breeding geese in the valleys of Svalbard provide a setting in which to test the apparent competition hypothesis (Jepsen et al. 2002; Eide et al. 2005).

The terrestrial ecosystem in the Svalbard archipelago is one of the world's most simple vertebrate tundra food webs (Ims et al. 2014). The main terrestrial resident generalist predator and scavenger is the Arctic fox Vulpes lagopus (Frafjord 1993; Prestrud 1992). 
Rodents are almost functionally absent in the ecosystem, apart from a small, local, geographically isolated population of sibling voles Microtes levis (Henttonen et al. 2001). In summer, the preferred food resource consists of eggs, chicks and adult Arctic-nesting geese (Pink-footed Goose Anser brachyrhynchus and Barnacle Goose Branta leucopsis). The increase in the populations of Pink-footed Goose (i.e. 15000 [1965] to 81500 [2012]; Madsen et al. 2016) and Barnacle Goose (i.e. 3000 - 4000 birds [1960's] to 35000 individuals [2008]; Mitchell et al. 2010) has been large and rapid. Seabirds (e.g. family Alcidae and Fulmar Fulmarus glacialis), remains of reindeer carcasses and occasionally newborn calves are typically secondary prey (Eide et al. 2005). In addition, Arctic fox V. lagopus can prey upon terrestrial ground nesting birds (Eide et al. 2005), many of which are of conservation concern due to their small populations in Svalbard. This includes the endemic Svalbard Rock Ptarmigan Lagopus muta hyperborea, locally red-listed waders living at the northern end of their range (Common Ringed Plover Charadrius hiaticula, Ringed Plover Charadrius hiaticula, Dunlin Calidris alpina, Sanderling Calidris alba, Red Phalarope Phalaropus fulicarius, Rednecked Phalarope Phalaropus lobatus, Ruddy Turnstone Arenaria interpres; Henriksen and Hilmo (2015)), and the only passerine, the Snow bunting Plectrophenax nivalis (Kovacs and Lydersen 2006). We expect these species to be incidental prey taken during the predator's search for preferred prey (see Cornell 1976), and for predation to be relatively limited due to their low abundances (Eide et al. 2005).

In this one-year observational study, we used artificial nests to compare the relative nest predation risk on small to medium sized ground-breeding birds (Svalbard Rock Ptarmigan L. muta hyperborea, small waders [Purple Sandpiper Calidris maritima and the seven locally red-listed waders described above] and Snow bunting $P$. nivalis) between two valleys that differed in abundance of nesting geese. According to the apparent competition 
hypothesis and McKinnon et al. (2013), we predicted higher predation rates on groundnesting birds in the study location with high abundance of nesting geese compared to the study location with low abundance of nesting geese due to increased spill-over predation by Arctic fox V. lagopus.

\section{Methods}

\section{Study area}

The high-Arctic archipelago of Svalbard, Norway $\left(62700 \mathrm{~km}^{2} ; 74-81^{\circ} \mathrm{N}, 15-30^{\circ} \mathrm{E}\right)$, has only 15 $\%$ of land covered with vegetation. Glaciers (60\%) and barren rocky ground ( $25 \%$ ) cover the remaining areas (Johansen et al. 2012). We conducted the study in the middle Arctic tundra zone of the largest island, Spitsbergen. The landscape is mountainous and moderately glaciated and continuous vegetation cover is only present in the valley bottoms and on the lower parts of the mountain slopes (Elvebakk 1999; Elvebakk 2005). The study sites are located in two adjacent open, u-shaped river valleys, Adventdalen and Sassendalen $\left(78^{\prime} 15^{\circ} \mathrm{N}\right.$, $17^{\prime} 20^{\circ} \mathrm{E}$; Fig. 1) which are characterized by differences in prey availability (Jepsen et al. 2002; Eide et al. 2004, 2005; see below for a description).

\section{Prey resource landscapes and predator abundance}

Former studies by Jepsen et al. (2002) and Eide et al. (2004, 2005) have characterized Adventdalen (termed 'prey-poor') as a poor prey resource landscape consisting mainly of reindeer, while Sassendalen (termed 'prey-rich') has richer prey resources consisting of both reindeer and geese (Fig. 1 and Table 1). The study locations have similar Svalbard reindeer $R$. t. platyrhynchus densities that show synchronous population dynamics (Aanes et al. 2003; Pedersen et al. 2014). Thus, we expect no significant differences between the study locations in the availability of reindeer carcasses as food for the Arctic fox $V$. lagopus (Jepsen 
et al. 2002; Eide et al. 2005). The abundance and density of Arctic-nesting geese (Pink-footed Goose and Barnacle Goose) differ between the study locations. The prey-rich study location is an important breeding area for Pink-footed Goose in Svalbard, in cliff habitat (e.g. $\mathrm{N} \varnothing$ isdalen cliff colony, area of $0.19 \mathrm{~km}^{2}$ ), there is a range of $25-55$ nests per colony and in open tundra slope (e.g. Gåseflatene slope colony, area $0.76 \mathrm{~km}^{2}$ ) there is a range of 170 230 nests per colony (see Anderson et al. 2015 for details and colony maps). In contrast, nesting geese are almost absent in the prey-poor study location (Mehlum et al. 1998; Eide et al. 2004, 2005; Wisz et al. 2008; Fig. 1). Both goose species incubate nests in June and most of the goslings have hatched around the beginning of July (Madsen et al. 2007) with posthatching aggregations forming along rivers and small lakes (Fox et al. 2009). Several large seabird cliff colonies are found in close proximity to the prey-rich study location (between 1 - $7 \mathrm{~km}$ from the transects), while they are further away in the prey-poor study location (between 16 - $20 \mathrm{~km}$ from the transects) (for additional details see Eide et al. 2004; Fig. 1 and Table 1). Fulmar F. glacialis, Brünnich's Guillemot Uria lomvia, Little Auk Alle alle and Puffins Fratercula arctica dominate these colonies. While all of these species are potential prey for the Arctic fox V. lagopus, Eide et al. (2005) found that geese, eggs, goslings and adult individuals were the preferred prey to seabirds and reindeer carcasses. In the absence of geese, seabirds were preferred to reindeer.

Diet studies of Arctic fox $V$. lagopus scats have documented that foxes also prey on Svalbard Rock Ptarmigan and smaller migratory birds such as waders and Snow buntings (Prestrud 1992; Eide et al. 2005). The ptarmigan is non-cyclic on Svalbard and has low breeding densities $\left(1.5-4.7\right.$ males $/ \mathrm{km}^{2}$ ) across the study locations (Soininen et al. 2016). Among the eight wader species commonly breeding in Svalbard, seven are locally red-listed (listed in the introduction; see also Henriksen and Hilmo 2015 for a complete species list). 
129 There is no information on abundances of Snow bunting or small waders within the two

130 study locations; however, we expect them to occur in low densities due to the high-Arctic

131 location of our study sites (Ims et al. 2014). In terms of predator abundance in the two study locations, the Arctic fox V. lagopus

133 den occupancy rate is slightly, but not statistically, higher in the prey-rich compared to the 134 prey-poor study location (see Figure 4b in Eide et al. 2012; Table 1 for occupancy rates in 1352012 study year). Currently, there is no knowledge about abundances of the avian predators, 136 the glaucous gull (Larus hyperboreas) and skuas (Stercorarius spp.), which scavenge and prey 137 upon the same resources as the Arctic fox V. lagopus.

\section{Study design}

139 We used an observational study design with artificial nests (cf. McKinnon et al. 2013) to 140 assess nest predation rates along transects spanning from the valley bottom to the upper 141 vegetation limit (altitude range; Adventdalen 110 - 384 masl., Sassendalen 3-182 masl., 142 Fig. 2). Thus, the transects represented both a gradient in terms of vegetation productivity and 143 type of nesting habitat (e.g. wetlands in the valley bottom, snow-bed/moss tundra in the

144 foothills, heath and ridge vegetation on the slopes and rocks with sparse vegetation at the upper 145 vegetation limit) for ground-nesting birds. We used 120 artificial nests deployed between $1^{\text {st }}$ 146 and $20^{\text {th }}$ July 2012 to obtain spatial replication and controlled stratification that would not 147 be possible using natural nests (McKinnon et al. 2010, 2013, 2014). This time-period covers 148 the main breeding season for the most common ground-nesting birds in Svalbard (e.g.

149 Svalbard Rock Ptarmigan L. muta hyperborea, Steen and Unander 1985; Snow bunting $P$. 150 nivalis, Hoset et al. 2004; Purple Sandpiper C. maritima, Summers and Nicoll 2004). This type 151 of study design provides information about spatial and temporal prevalence of egg152 consuming predators, thus indicating relative predation-risk patterns for ground-nesting 
153 birds from both mammalian and avian predators (e.g. Angelstam 1986; Storch 1991; Villard 154 and Part 2004; Manzer and Hannon 2005; McKinnon et al. 2010). Based on a random start position, we placed 12 transects in each study location with five artificial nests in each transect $(N=60$ artificial nests per study location; total $N=120$;

Fig. 1). In the prey-poor study location, we placed the 12 transects adjacent to each other on one side of a large glacial river due to difficulties involved in crossing the river. In the preyrich study location, we placed six transects on each side of a large glacial river which could act as a barrier for Arctic fox $V$. lagopus movement in summer. The overall mean distance between transects was 1190 m (range [932 - 2852 m]) and differed slightly between study

162 locations (prey-poor, mean = $1099 \mathrm{~m}$, range [932 - $1701 \mathrm{~m}]$; prey-rich, mean = $1281 \mathrm{~m}$, 163 range [1004-2852 m]). The overall mean transect length was $911 \mathrm{~m}$ (range [99 - $1652 \mathrm{~m}]$ ) 164 and differed also slightly between study locations (prey-poor, mean = $994 \mathrm{~m}$, range [99165 $1652 \mathrm{~m}]$, the lowest number is due to that only two nests were placed in this short transect 166 due to topographical constraints; prey-rich, mean $=828 \mathrm{~m}$, range [381 - $1401 \mathrm{~m}]$ ). The 167 artificial nests $(n=5)$ were deployed at equal distance intervals along a low to high elevation 168 gradient of individual transects. Due to varying transect length the mean distance between 169 two artificial nests was $239 \mathrm{~m}$ (range [99- $558 \mathrm{~m}]$ ).

171 placed in sparsely vegetated habitats with less than $25 \%$ vegetation cover. Post fieldwork 172 we assigned each artificial nest site a habitat type using the digital habitat map of Johansen 173 et al. (2012) that defines 18 habitat classes (see Johansen et al. 2012, Table 2 for habitat 174 classes). Prior to analysis, we reclassified the habitat types into four coarse habitat 175 productivity categories assumed to be relevant for the breeding ecology of ground-nesting 176 birds in the study areas. These were barren (original classes $4-6,8,17$ and 18; $n=40$ ), moist 
177 (original classes 9, 12 and 15; $n=74$ ), wet (original classes 10 and $11 ; n=29$ ) and dry

178 (original classes 13,14 and $16 ; n=26$ ) (Fig. 2). Since many of the plots were located in an

179 unclassified habitat type (original class $7 ; n=57$ ), we added a fifth vegetation category 'not

180 classified' to our habitat variable (Fig. 2).

\section{Artificial nests}

182 Each nest consisted of two commercially produced common quail eggs Coturnix coturnix that

183 were placed on the ground in a small, shallow hand-made nest cup to imitate nest

184 characteristics of the most common bird species. We followed McKinnon et al. (2013) in

185 assuming that exposure of eggs in artificial nests provided a measure of relative predation

186 risk on small to medium-sized ground-nesting birds. To reduce human scent we wore latex

187 gloves and rubber boots or plastic covered hiking-boots when handling the eggs, and we left

188 only plastic covered equipment on the ground (Bowen 1976). We noted the GPS position of

189 each nest and placed a small orange coloured wooden stick $(7 \mathrm{~mm}$ in diameter, $2-5 \mathrm{~cm}$

190 above ground) $5 \mathrm{~m}$ above or below the nest in the direction of the transect line to aid nest

191 relocation. We exposed the nests to predators for two consecutive trial periods of 10 days to

192 account for potential temporal differences in predation rates. The nests were set out for the

193 first time on $1^{\text {st }}$ July, which coincided with the incubation period of the most common

194 ground-nesting bird species (Svalbard Rock Ptarmigan, Steen and Unander 1985; Snow

195 bunting, Hoset et al. 2004; purple sandpiper, Summers and Nicoll 2004). The nests were

196 visited every 10 days (two visits) and we recorded a nest as predated when at least one of

197 the eggs was missing, destroyed or distributed in the immediate surroundings of the nest

198 site. 
199

200

201

202

203

204

205

206

207

208

209

\section{Results}

217 Nest predation was consistently high in both study locations with more than half of all the

218 artificial nests being predated (Table 2). A simple model including only the predictor variable

219 location explained best the nest predation risks (Fig. 3, Table 3 - 4). There was no support for 220 any effects of period or habitat type on predation rates. The probability of nest predation 
221 was significantly higher in the prey-poor location (88\%), compared to the prey-rich location

222 (62\%) (odds ratio [OR] prey-poor/ prey-rich = 4.6, $95 \% \mathrm{Cl}=1.5-14.2$; Fig. 3).

\section{Discussion}

224 Our results indicate that nest predation risk of ground-nesting birds (Svalbard Rock

Ptarmigan L. muta hyperborea, small waders (listed in introduction) and Snow bunting $P$.

nivalis) was lower in tundra landscapes with high abundances of geese, the preferred prey of

Arctic fox $V$. lagopus. These results contrast with those from several structurally more

complex Arctic ecosystems where presence of goose colonies led to elevated predation rates on other ground-nesting birds (Iles et al. 2013; McKinnon et al. 2013, 2014). Our results thus demonstrate the first indications that an allochtonous resource, in the form of abundant migratory geese from temperate ecosystems, influences nest predation risk in a tundra ecosystem lacking small rodents.

Based on the apparent competition hypothesis and results from the study by McKinnon et al. (2013), we expected nest predation risk on ground-nesting birds to be higher in the prey-rich compared to the prey-poor study location. Our results indicated the opposite, with an almost five-fold decrease in relative nest predation rates in the prey-rich location and are therefore compatible with an apparent mutualism mechanism (Abrahams and Matsuda 1996), where less abundant alternative prey benefit from high abundances of main prey.

Whether alternative prey benefit from being interspersed amongst the main prey of a 240 shared predator is dependent on the functional and numerical response of the predator, as 241 well as the relative abundance of the different prey species and their spatial and temporal 242 distributions (Barraquand et al. 2015). The contrasting findings to McKinnon et al. (2013) 243 may relate to differences in both abundance of main goose prey and spatial study scale, i.e. 244 local (McKinnon et al. 2013) versus landscape scale (this study). McKinnon et al.'s (2013) 
study placed the artificial nests in the centre of a large snow-goose colony (i.e. approx. 50

000 individuals, four nests were set out in each of 10 quadrats of $500 \times 500 \mathrm{~m}$ with varying

247 goose nest density). In our study, we dispersed the artificial nests along elevation gradients

248 representing different types of ground-nesting bird habitats, in tundra landscapes that

249 contained either no goose nests or colonies spread across the hill-slopes or on smaller cliffs

250 (Anderson et al. 2015; see their Table 1). McKinnon et al.'s (2013) study suggested an

251 aggregative search response of Arctic fox V. lagopus and indeed such behaviour might

252 happen in our study area and be directly comparable. However, as the density of the goose

253 nests is much lower in our study, the search response (and hence overspill predation) may

254 be confined to sections of the landscape where geese are present (Jepsen et al. 2002). Thus,

255 for ground-nesting birds that nest in low densities, a heterogenic aggregative search

256 response of the Arctic fox $V$. lagopus may result in a reduction in the overall predation

257 pressure on these species.

258 At the time of the study $\left(1^{\text {st }}-20^{\text {th }}\right.$ July) many geese have already hatched their eggs,

259 while many of the other ground-nesting birds are still incubating. Former studies have

260 demonstrated that goose prey distribution can concentrate the aggregation of Arctic foxes

261 V. lagopus to certain parts of the landscape where geese congregate such as flooded areas,

262 small lakes and along river banks (Jepsen et al. 2002; Fox et al. 2009). Thus, the presence of

263 goose family groups in these areas is likely to influence the spatial pattern of fox distribution.

264 This may result in reduced time spent by the fox in the nesting habitats of other less

265 common ground-nesting birds. Seabird colonies may also act in a similar way and reduce

266 local predation pressure on other ground-nesting birds. As such, the short distance to bird

267 cliffs in the prey-rich location may also have contributed to reduced nest predation rates on

268 the ground-nesting birds in this location. In the prey-poor location, the high nest predation 
269

270

271

272

273

274

275

276

may simply result from virtually no other prey present than ground-nesting birds in summer, which leads to high search effort by Arctic foxes $V$. lagopus for ground-nesting bird nests. Additionally, potential differences in abundance of the bird predator communities (e.g. Glaucous gull Larus hyperboreus and skuas Stercorarius spp.) may contribute to this pattern as demonstrated by lles et al. (2013) in a more complex ecosystem. While no information currently exists to evaluate this effect, the lack of both habitat and time period effects in our study indicate a continuous predation pressure from both Arctic fox $V$. lagopus and avian predators during the 2012 season.

Another plausible explanation for the lower predation risk in the prey-rich location is a prey swamping effect whereby high abundances of geese buffer predation of less abundant prey (Robertson 1995, Gauthier et al. 2004, lles et al. 2013). This is documented in other Arctic ecosystems where goose-nesting colonies buffered predation on vulnerable tundra birds from e.g. Snowy Owls Bubo scandiacus (Gauthier et al. 2004). Indeed, such an effect from a temporally pulsed resource, such as goose nests and goose family groups, are most likely if they are dispersed across the landscape, as occurs in the Svalbard breeding Pinkfooted Goose A. brachyrhynchus populations rather than being highly concentrated spatially (Ims 1990).

There are many shortcomings of artificial nest studies, which may lead to a discrepancy between absolute predation rates of real and artificial nets. These include the lack of an incubating bird and associated nest defence, as well as the limited ability to identify predator species (reviewed in Moore and Robinson 2004). We argue, however, that as we use a standardised study design applied in other studies of relative predation risk in similar open habitats (see McKinnon et al. 2010, 2013, 2014), we capture the relative nest predation risk from the predator community on the less common prey species. We thus suggest that 
experiments with artificial nests should be part of long-term monitoring efforts. Such an

294

295

include methods that enable identification of the nest predator species (mammalian versus

297 avian egg predators; McKinnon et al. (2009)), as well as improved data on the abundance 298 and distribution of the nests of geese and other ground-nesting birds. Implementation of the approach allows estimation of the inter-annual variability and climate-change related trends in nest predation rates in areas of different prey abundances. The monitoring should also "Climate-Ecological Observatory for Arctic Tundra", which is an adaptive ecosystem-based long-term monitoring program covering our study regions (Ims et al. 2013), along with circumpolar initiatives such as "The Arctic Migratory Birds Initiative" (Johnston et al. 2015), are important steps to enhance the knowledgebase. This will advance our understanding of the interactive effects between the Arctic fox $V$. lagopus, avian predators / scavengers and goose abundance on terrestrial high-Arctic birds of conservation concern, thus, allowing for the effective appraisal of management actions that can reduce their vulnerability to extinction.

\section{Acknowledgement}

Funding for this study was provided by the Fram Centre, the Norwegian Polar Institute, the Norwegian Institute for Nature Research and the University Centre in Svalbard. We thank the field assistants for their hard work in the field: Kaisa Boll, Daniels Karin Amby, Charmain Hamilton, Aino M. Kokkonen, Inka Lipasti, Yann Rashid, Silje Rekdal Larsen and Simon Rilling. We also thank Jesper Madsen and two anonymous reviewers and the chief-editor, Dieter Piepenburg, for valuable comments on the manuscript, Virve Ravolainen for assistance with the vegetation data and Oddveig Øien Ørvoll for graphical design of maps. The study complied with the current regulations in the Svalbard Environmental Protection Act. 


\section{References}

317 Aanes R, Saether BE, Solberg EJ, Aanes S, Strand O, Oritsland NA (2003) Synchrony in Svalbard reindeer population dynamics. Candian J Zoology 81:103-110

Abrams PA, Holt RD, Roth RD (1998) Apparent competition or apparent mutualism? shared predation when populations cycle. Ecology 79:201-212

Abrams PA, Matsuda H (1996) Positive indirect effects between prey species that share predators. Ecology 77:610-616

Anderson DR, Burnham KP (2002). Avoiding pitfalls when using information-theoretic methods. J Wildl Management 66:912-918

Anderson HB, Madsen J, Fuglei E, Jensen GH, Woodin SJ, van der Wal R (2015) The dilemma of where to nest: influence of spring snow cover, food proximity and predator abundance on reproductive success of an Arctic-breeding migratory herbivore is dependent on nesting habitat choice. Polar Biol 38:153-162

Angelstam P (1986) Predation on ground-nesting birds nests in relation to predator densities and habitat edge. Oikos 47:365-373

Barraquand F, New LF, Redpath S, Matthiopoulos J. (2015). Indirect effect of primary prey population dynamics on alternative prey. Theor Popul Biol 103: 44-59.

Bates D, Mächler M, Bolker BM, Walker SC (2015) Fitting linear mixed-effects models using Ime4. J Stat Software 67

Bety J, Gauthier G, Giroux JF, Korpimaki E (2001) Are goose nesting success and lemming cycles linked? Interplay between nest density and predators Oikos 93:388-400

Bowen DE, Robel, R.J. \& Watt, P.G. (1976) Habitat and investigators influence artificial ground nest losses: Kansas. Trans Kans Acad Sci 79:141-147 
Cornell H (1976) Search strategies and adaptive significance of switching in some general predators. Am Naturalist110:317-320

Eide NE, Eid PM, Prestrud P, Swenson JE (2005) Dietary responses of Arctic foxes Alopex lagopus to changing prey availability across an Arctic landscape. Wildl Biol 11:109121

Eide NE, Jepsen JU, Prestrud P (2004) Spatial organization of reproductive Arctic foxes Alopex lagopus: responses to changes in spatial and temporal availability of prey. J Anim Ecol 73:1056-1068

Eide NE, Stien A, Prestrud P, Yoccoz NG, Fuglei E (2012) Reproductive responses to spatial and temporal prey availability in a coastal Arctic fox population. J Anim Ecol 81:640648

Elvebakk A (1999) Bioclimatic delimitation and subdivision of the Arctic. In: Nordal I and Razzhivin VY (eds) The species concept in the high north - A panarctic flora initiative. Norske Videnskaps-Akademi, Oslo, pp 81-112

Elvebakk A (2005) A vegetation map of Svalbard on the scale 1 : 3.5 mill. Phytocoenologia $35: 951-967$

Fox TAD, Eide NE, Bergersen E, Madsen J (2009) Resource partitioning in sympatric Arcticbreeding geese: summer habitat use, spatial and dietary overlap of Barnacle and Pink-footed Geese in Svalbard. Ibis 151:122-133

Frafjord, K. 1993. Food habits of Arctic foxes (Alopex lagopus) on the Western coast of Svalbard. Arctic 46:49-54.Fuglei E, Oritsland NA, Prestrud P (2003) Local variation in Arctic fox abundance on Svalbard, Norway. Polar Biol 26:93-98

Gauthier G, Bêty J, Giroux JF, Rochefort L (2004). Trophic interactions in a high-Arctic snow goose colony. International Comparative Biol 44:119-129 
Giroux MA, Berteaux D, Lecomte N, Gauthier G, Szor G, Bety J (2012) Benefiting from a migratory prey: spatio-temporal patterns in allochthonous subsidization of an Arctic predator. J Anim Ecol 81:533-542

Henriksen S, Hilmo O (2015) Norsk rødliste for arter 2015. Artsdatabanken, Trondheim (in Norwegian)

Henttonen H, Fuglei E, Gower CN, Haukisalmi V, Ims RA, Niemimaa J, Yoccoz NG (2001) Echinococcus multilocularis on Svalbard: introduction of an intermediate host has enabled the local life-cycle. Parasitology 123:547-552

Holt RD, Kotler BP (1987) Short-term apparent competition. Am Naturalist 130:412-430

Hoset KS, Espmark Y, Moksnes A, Haugan T, Ingebrigtsen M, Lier M (2004) Effect of ambient temperature on food provisioning and reproductive success in Snow buntings Plectrophenax nivalis in the high -Arctic. Ardea 92:239-246

Iles DT, Rockwell RF, Matulonis P, Robertson GJ, Abraham KF, Davies JC, Koons DN (2013) Predators, alternative prey and climate influence annual breeding success of a longlived sea duck. J Anim Ecol 82:683-693

Ims RA (1990) On the adaptive value of reproductive synchrony as a predator-swamping strategy. Am Naturalist 136:485-498

Ims RA, Alsos IG, Fuglei E, Pedersen $\AA \varnothing$, Yoccoz NG (2014) An assessment of MOSJ - The state of the terrestrial environment in Svalbard. Report 144, Norwegian Polar Institute, Troms $\varnothing$

Ims RA, Jepsen JU, Stien A, Yoccoz NG (2013). Science Plan for COAT: Climate-ecological Observatory for Arctic Tundra. Fram Centre, Troms $\varnothing$

Jepsen JU, Eide NE, Prestrud P, Jacobsen LB (2002) The importance of prey distribution in habitat use by Arctic foxes (Alopex lagopus) Canadian J Zool 80:418-429 
Johansen BE, Karlsen SR, Tommervik H (2012) Vegetation mapping of Svalbard utilising Landsat TM/ETM plus data. Polar Rec 48:47-63

Johnston V, Syroechkovskiy E, Crockford N, Lanctot RB, Millington S, Clay R, Donaldson G, Ekker M, Gilchrist G, Black A, Crawford R (2015) Arctic Migratory Birds Initiative (AMBI): Workplan 2015-2019. CAFF Strategies Series No. 6. Conservation of Arctic Flora and Fauna, Akureyri, Iceland. ISBN: 978-9935-431-40-OKovacs KM, Lydersen C (2006) Birds and mammals of Svalbard. Norwegian Polar Institute, Troms $\varnothing$

Legagneux P et al. (2012) Disentangling trophic relationships in a high-Arctic tundra ecosystem through food web modeling. Ecology 93:1707-1716

Legagneux P et al. (2014) Arctic ecosystem structure and functioning shaped by climate and herbivore body size. Nature Climate Change 4:379-383

Lewis KP (2004) How important is the statistical approach for analyzing categorical data? A critique using artificial nests. Oikos 104:305-315

Madsen J et al. (2007) Effects of snow cover on the timing and success of reproduction in high-Arctic pink-footed geese Anser brachyrhynchus. Polar Biol 30:1363-1372

Madsen J et al. (2016). Svalbard pink-footed goose. population status report 2015-2016. Technical report from Danish Centre for Environment and Energy, No. 83. Aarhus University and Danish Centre for Environment and Energy

Manzer DL, Hannon SJ (2005) Relating grouse nest success and corvid density to habitat: A multi-scale approach. J Wildl Management 69:110-123.

McKinnon L, Berteaux D, Bêty J (2014) Predator-mediated interactions between lemmings and shorebirds: a test of the alternative prey hypothesis. Auk 131(4):619-628

McKinnon L, Berteaux D, Gauthier G, Bety J (2013) Predator-mediated interactions between preferred, alternative and incidental prey in the Arctic tundra. Oikos 122:1042-1048 
411 McKinnon L et al. (2010) Lower predation risk for migratory birds at high latitudes. Science $327: 326-327$

413

Mehlum F, Black J, Madsen Je (1998) Research on Arctic geese : proceedings of the Svalbard Goose Symposium, Oslo, Norway, 23-26 September 1997. Report 200, Norwegian Polar Institute, Troms $\varnothing$

Mitchell C et al. (2010) Trends in goose numbers wintering in Britain \& Ireland, 1995 to 2008. Ornis Svecica 20:128-143

Moore RP, Robinson WD (2004) Artificial bird nests, external validity, and bias in ecological field studies Ecology 85:1562-1567

Pedersen Å $\varnothing$, Bårdsen BJ, Veiberg V, Hansen BB (2014) Jegernes egne data. Analyser av jaktstatistikk og kjevemateriale fra svalbardrein. Kortrapport 27, Norsk Polarinstitutt, Troms $\varnothing$ (in Norwegian)

Prestrud P (1992) Food-habits and observations of the hunting behavior of Arctic foxes, Alopex-Lagopus, in Svalbard. Canadian Field Naturalist 106:225-236.

Robertson GJ (1995) Factors affecting nest site selection and nesting success in the common eider Somateria mollissima. Ibis 137:109-115

Roth JD (2003) Variability in marine resources affects Arctic fox population dynamics. J Anim Ecol 72:668-676

Soininen E, Fuglei E, PEdersen $\AA \varnothing$ (2016) Complementary use of density estimates and hunting statistics: different sides of the same story? Eur J Wildl Res 62(2): 151-160

Steen JB, Unander S (1985) Breeding biology of the Svalbard Rock Ptarmigan Lagopus mutus hyperboreus. Ornis Scand 16:191-197

Storch I (1991) Habitat fragmentation, nest site selection, and nest predation risk in capercaillie. Ornis Scand 22:213-217 
435 Summers RW, Nicoll M (2004) Geographical variation in the breeding biology of the Purple $436 \quad$ Sandpiper Calidris maritima. Ibis 146:303-313

437 Tombre IM, Black JM, Loonen MJJE (1998) Critical components in the dynamics of a barnacle 438 goose colony: a sensitivity analysis. Skrifter 200, Norwegian Polar Institute, Troms $\varnothing$ 439 Villard MA, Part T (2004) Don't put all your eggs in real nests: a Sequel to Faaborg. Conserv 440 Biol 18:371-372

441 Wisz M et al. (2008) Modelling pink-footed goose (Anser brachyrhynchus) wintering distributions for the year 2050: potential effects of land-use change in Europe. Divers and Distrib 14:721-73 


\section{Tables}

Table 1 Summary of prey and predator characteristics of the two study locations, the prey-poor inland resource landscape with low goose

give also Arctic fox Vulpes lagopus den occupancy rates for the 2012 study year

\begin{tabular}{|c|c|c|}
\hline STUDY LOCATION CHARACTERISTICS & PREY-POOR & PREY-RICH \\
\hline $\begin{array}{l}\text { Goose abundance } \\
\text { (Eide et al. 2004; 2005, Wisz et al. 2008; GOOSEMAP }{ }^{1)} \text { ) }\end{array}$ & Lower & Higher \\
\hline \multirow[t]{2}{*}{$\begin{array}{l}\text { Seabird colonies } \\
\text { (Eide et al. 2004; NPI Seabird database }{ }^{2)} \text { ) }\end{array}$} & $\begin{array}{l}\text { Longer distance from Arctic fox } \\
\text { natal den }\end{array}$ & $\begin{array}{l}\text { Shorter distance from Arctic fox } \\
\text { natal den }\end{array}$ \\
\hline & Mean $=13.5 \mathrm{~km}( \pm 4.32)$ & Mean $=8.69 \mathrm{~km}( \pm 3.79)$ \\
\hline $\begin{array}{l}\text { Access to other marine resources } \\
\text { (Seal carcasses and pups on sea ice or at glacier fronts; Eide et al. } \\
\text { 2012) }\end{array}$ & $\begin{array}{l}\text { Longer distance from Arctic fox } \\
\text { natal den }\end{array}$ & $\begin{array}{l}\text { Shorter distance from Arctic fox } \\
\text { natal den }\end{array}$ \\
\hline $\begin{array}{l}\text { Reindeer density and carcass availability } \\
\text { (Jepsen et al. 2002; Eide at al. 2005, Pedersen et al. 2014) }\end{array}$ & Similar & Similar \\
\hline $\begin{array}{l}\text { Arctic fox den occupancy } 1984-89 \text { and 1997-2001- } \\
\text { (Based on estimates from Eide et al. 2012; see Fig. 4b) }\end{array}$ & Lower & Higher \\
\hline \multirow{2}{*}{$\begin{array}{l}\text { Arctic fox den occupancy } 2012 \\
\text { (Fuglei unpublished) }\end{array}$} & $\mathrm{N}$ monitored dens $=10$ & $\mathrm{~N}$ monitored dens $=10$ \\
\hline & N occupied dens $=4$ (40\%) & N occupied dens $=4(40 \%)$ \\
\hline
\end{tabular}

1) www.goosemap.nina.no

449 2) http://svalbardkartet.npolar.no/Viewer.html?Viewer=Svalbardkartet. 
450 Table 2 Summary of artificial nest predation by study location (prey-rich $=$ high goose

451 abundance; prey-poor = low goose abundance; Fig. 1 ) and time period (period $1=1^{\text {st }}-10^{\text {th }}$

452 July; period $2=10^{\text {th }}-20^{\text {th }}$ July) the nests were available for predation. Total predation $=$ the

453 number of eggs depredated. Nest = the total number of artificial nests available for

454 predation

\begin{tabular}{lcccc}
\hline & \multicolumn{2}{c}{ Prey-rich } & \multicolumn{2}{c}{ Prey-poor } \\
\cline { 2 - 5 } & Period 1 & Period 2 & Period 1 & Period 2 \\
\hline Total predation & $30(57 \%)$ & $35(59 \%)$ & $43(75 \%)$ & $51(89)$ \\
Nest $(\mathrm{n})$ & 53 & 59 & 57 & 57 \\
\hline
\end{tabular}

455 
Table 3 Ranking of the five best generalized linear mixed-effect models for assessment of relative nest predation risk on small to medium-sized ground-nesting birds (e.g. Svalbard Rock Ptarmigan Lagopus muta hyperborea, small waders [Common Ringed Plover Charadrius hiaticula, Ringed Plover Charadrius hiaticula, Dunlin Calidris alpina, Purple Sandpiper Calidris maritima, Sanderling Calidris alba, Red Phalarope Phalaropus fulicarius, Red-necked Phalarope Phalaropus lobatus, Ruddy Turnstone Arenaria interpres; Henriksen and Hilmo (2015)] and the Snow bunting Plectrophenax nivalis ) in the prey-rich (high goose abundance) and the prey-poor (low goose abundance) study locations.; Fig. used for inference

\begin{tabular}{|c|c|c|c|c|c|c|c|c|c|}
\hline Model rank & Location & Period & Habitat & Location $\times$ Period & Location $\times$ Habitat & $\mathrm{K}$ & $\mathrm{AIC}_{\mathrm{c}}$ & $\Delta \mathrm{AIC}_{\mathrm{c}}$ & $\mathrm{AIC}_{\mathrm{c} \text { weights }}$ \\
\hline 1 & $x$ & $x$ & & & - & 5 & 256.12 & 0.00 & 0.50 \\
\hline 2 & $x$ & & & & - & 4 & 256.38 & 0.26 & 0.44 \\
\hline 3 & & & $x$ & $x$ & - & 10 & 262.58 & 6.46 & 0.02 \\
\hline 4 & $x$ & $x$ & $x$ & & - & 9 & 262.89 & 6.77 & 0.02 \\
\hline 5 & $x$ & & $x$ & & - & 8 & 263.06 & 6.94 & 0.02 \\
\hline
\end{tabular}


465 Table 4 Estimated effect sizes (on the logit scale) from the selected model describing 466 artificial nest predation risks in the two study locations contrasted by prey resources (prey467 rich = high goose abundance; prey-poor = low goose abundance; Fig. 1). Coefficients for the 468 random effect variables and residual variability are standard deviations. Residual degrees of 469 freedom $=222$

\begin{tabular}{llccc}
\hline Explanatory variable & Estimate & SE & $\boldsymbol{p}$ \\
\hline Fixed & Intercept (prey-rich location) & 0.49 & 0.37 & 0.18 \\
& Location (prey-poor location) & 1.53 & 0.57 & $<0.01$ \\
& Transect x Plot & 0.92 & & \\
& Transect & 0.87 & & \\
& & & & \\
\hline
\end{tabular}

470 


\section{Figures legends}

472 Fig. 1 Location of the study area with the spatial design of the 24 transects for assessing

473 relative nest predation risks in two study locations contrasted by prey resources

474 (Adventdalen $=$ prey-poor $[$ low goose abundance]; Sassendalen $=$ prey-rich $[$ high goose

475 abundance]; see Jepsen et al. 2002, Eide $t$ al. 2004). The transects span along a vegetation

476 productivity gradient from the valley bottom to the upper vegetation limit at higher

477 elevations. Symbols indicate the distribution of goose breeding grounds and seabird

478 colonies. The inset shows the study area on the Svalbard archipelago. The figure is modified

479 after Eide et al. (2004; Fig. 1)

480 Fig. 2 Habitat and altitude characteristics for assessing relative nest predation risk in the 481 prey-poor and prey-rich study locations between $1^{\text {st }}$ and $20^{\text {th }}$ July in 2012 . . The bar-plots (a -

482 c) show the proportion of the habitat types across: a) the prey-poor and prey-rich study

483 locations; b) plots in the prey-poor study location; and c) plots in the prey-rich study

484 location. The box-plots $(d-f)$ show the altitude $(m)$ across: $d)$ the prey-poor and prey-rich

485 study locations; e) plots in the prey-poor study location; and f) plots in the prey-rich study 486 location. 


\section{$487 \quad$ Figures}

$488 \quad$ Fig. 1

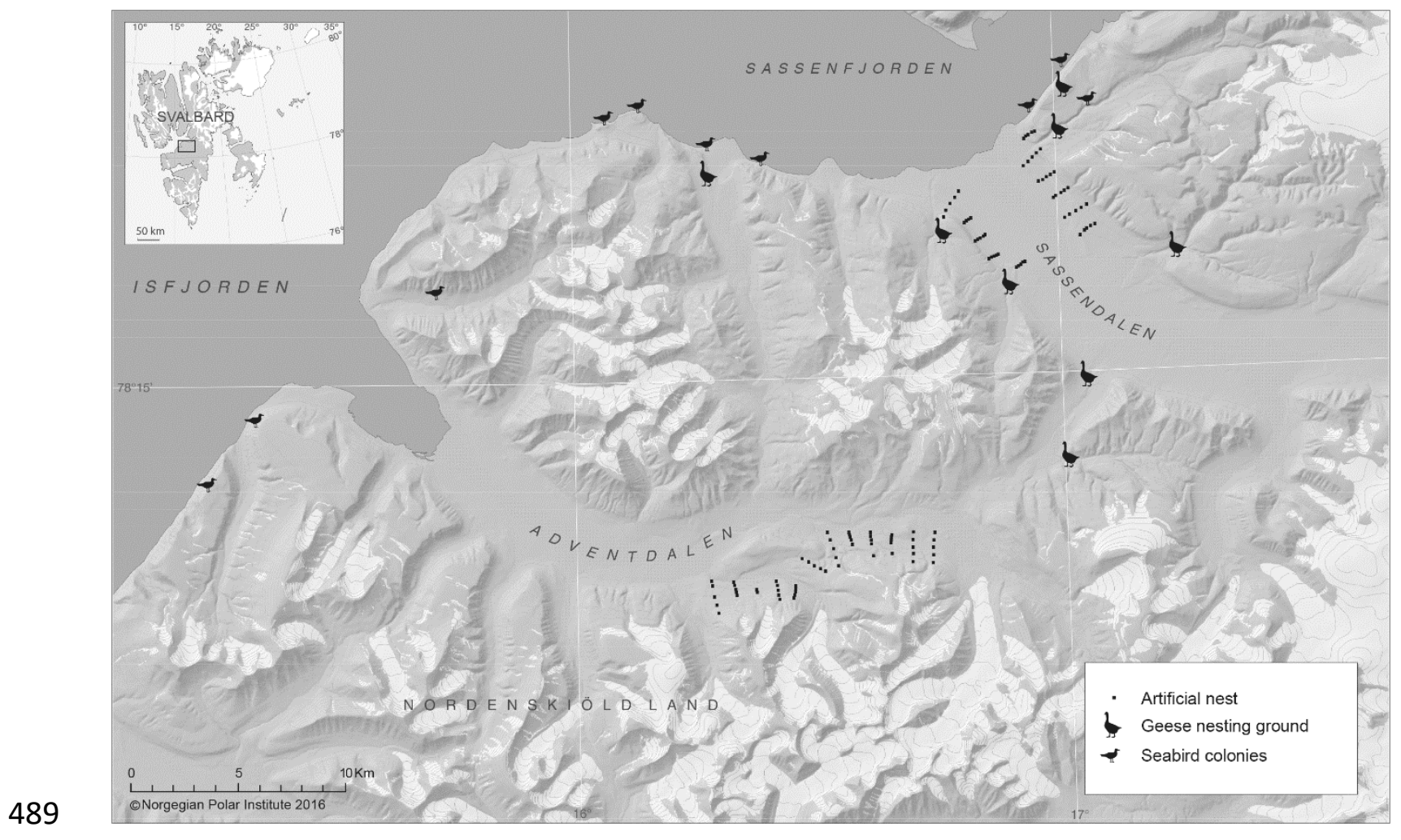


Fig. 2

a)

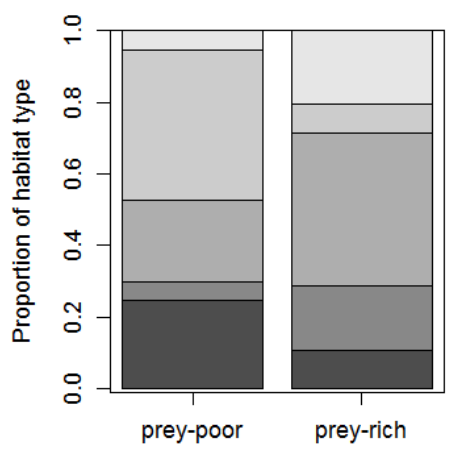

b)

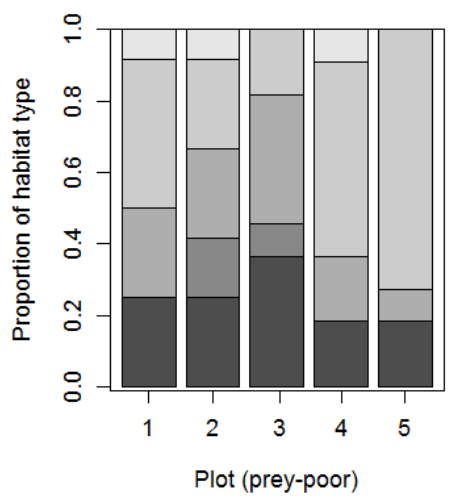

c)

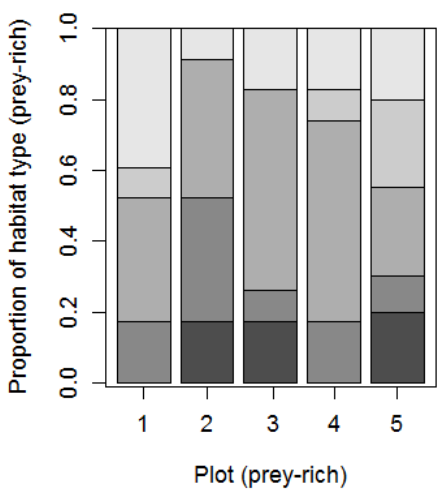

491 d)

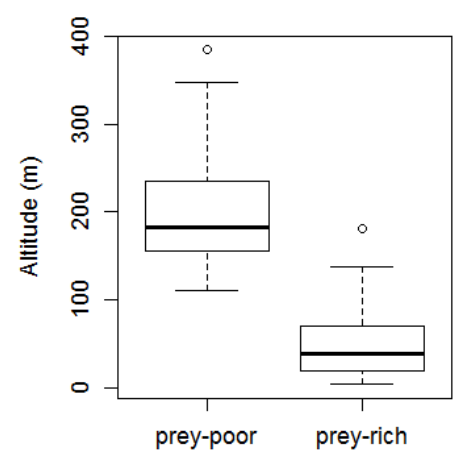

$\square$ not classified

$\square$ dry

$\square$ wet

$\square$ moist

barren

e)

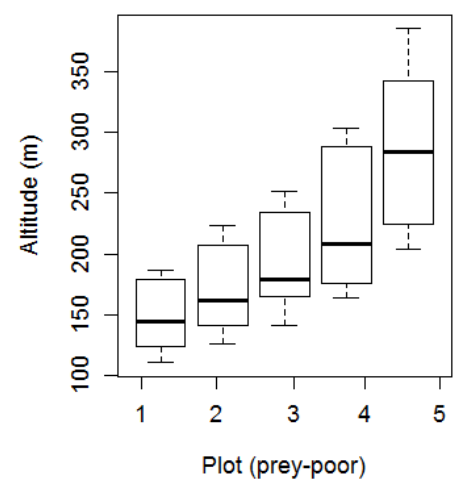

f)

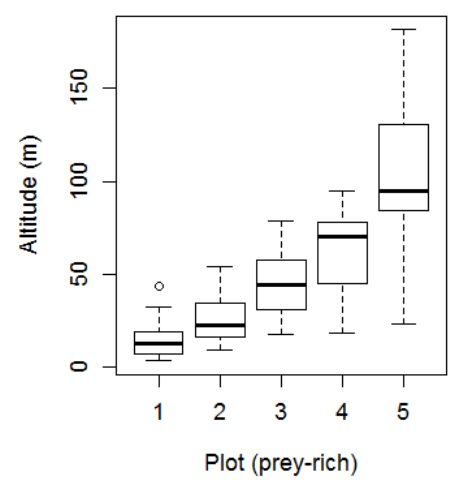

